\title{
Influence of temperature on the larval development of the edible crab, Cancer pagurus
}

\author{
MONIKA WEISS $^{1}$, SVEN THATJE ${ }^{2}$, OLAF HEILMAYER ${ }^{1,2}$, KLAUS ANGER $^{3}$, THOMAS BREY $^{1}$ \\ AND MARTINA KELLER ${ }^{1}$ \\ ${ }^{1}$ Alfred-Wegener-Institut für Polar-und Meeresforschung, Am Handelshafen 12, 27570 Bremerhaven, Germany, ${ }^{2}$ National \\ Oceanography Centre, Southampton, School of Ocean and Earth Science, University of Southampton, European Way, SO14 3ZH \\ Southampton, United Kingdom, ${ }^{3}$ Biologische Anstalt Helgoland, Stiftung Alfred-Wegener-Institut für Polar- und Meeresforschung, \\ 27498 Helgoland, Germany
}

\begin{abstract}
The influence of temperature on larval survival and development was studied in the edible crab, Cancer pagurus, from a population off the island of Helgoland, North Sea. In rearing experiments conducted at six different temperatures $\left(6^{\circ}, 10^{\circ}\right.$, $14^{\circ}, 15^{\circ}, 18^{\circ}$ and $24^{\circ} \mathrm{C}$ ), zoeal development was only completed at $14^{\circ}$ and $15^{\circ} \mathrm{C}$. Instar duration of the Zoea I was negatively correlated with temperature. A model relating larval body mass to temperature and developmental time suggests that successful larval development is possible within a narrow temperature range $\left(14^{\circ} \pm 3^{\circ} \mathrm{C}\right)$ only. This temperature optimum coincides with the highest citrate synthase activity found at $14^{\circ} \mathrm{C}$. A comparison for intraspecific variability among freshly hatched zoeae from different females $(C W 13-17 \mathrm{~cm}, N=8)$ revealed that both body mass and elemental composition varied significantly. Initial larval dry weight ranged from 12.1 to $17.9 \mu \mathrm{g} /$ individual, the carbon content from 4.6 to $5.8 \mu \mathrm{g} /$ individual, nitrogen from 1.1 to $1.3 \mu \mathrm{g} /$ individual, and the C:N ratio from 4.1 to 4.4. A narrow larval temperature tolerance range of $\mathrm{C}$. pagurus as well as the indication of intraspecific variability in female energy allocation into eggs may indicate a potential vulnerability of this species to climate change. Large-scale studies on the ecological and physiological resilience potential of this commercially fished predator are needed.
\end{abstract}

Keywords: Brachyura, early ontogeny, edible crab, elemental composition

Submitted 29 May 2008; accepted 22 October 2008; first published online 20 January 2009

\section{INTRDDUCTION}

The embryonic and larval development of marine invertebrates is affected by extrinsic and intrinsic factors, such as temperature, maternal energy provisioning (Ouellet \& Plante, 2004) and both pre- and post-hatching environmental conditions (Torres \& Escribano, 2003; Giménez et al., 2004; Fischer \& Thatje, 2008). Variation in environmental key factors such as food availability (Anger \& Dawirs, 1982), quality (Harms et al., 1991), salinity (Giménez \& Torres, 2002; Giménez \& Anger, 2003) or temperature (Dawirs, 1979, 1985) can have unfavourable effects on growth in the early ontogeny of decapod crustaceans (for review, see Anger, 2001).

The early life cycle of the edible crab, Cancer pagurus, consists of five planktotrophic zoeal stages and a megalopa before reaching the first crab stage (Ingle, 1981). This species has a broad geographical distribution from northern Norway to West Africa and is also abundant in the Mediterranean Sea, which implies a wide range of temperature tolerance in adult populations of the species. Studies of abundance and catch rates show that $C$. pagurus is expanding its biogeographical range further northwards (Woll et al., 2006).

Corresponding author:

S. Thatje

Email: svth@noc.soton.ac.uk
Since 1962 mean annual sea-surface temperature in the North Sea around the island of Helgoland rose $1.1^{\circ} \mathrm{C}$, with milder winters and rising summer maxima (Wiltshire \& Manly, 2004). Such a shift in ecological conditions may cause changes in the metabolic efficiency or fitness of an organism (Pörtner, 2001; Heilmayer et al., 2004), which presumably is reflected in its elemental and biochemical composition (Dahlhoff, 2004). Studies on the complete temperature tolerance window of invertebrate larvae are extremely scarce, but may be a clue in future assessments of the potential of species to cope with climate change (e.g. Anger, 2001; Pörtner et al., 2001, 2005; Thatje et al., 2005).

In the present study, we provide evidence for temperatureinduced changes in the chemical composition and aerobic capacities of C. pagurus larvae. Based on the hypothesis that the early ontogeny is the most vulnerable part of a life cycle (Anger, 2001), we discuss the physiological capability of the species to cope with elevated temperatures.

\section{MATERIALS AND METHDDS}

\section{Sampling and maintenance of adults and larvae}

Ovigerous Cancer pagurus (carapace width (CW) 125 to $171 \mathrm{~mm}$ ) were caught in May 2005 near the island of Helgoland in the North Sea $\left(54^{\circ} 11^{\prime} \mathrm{N}^{\circ} 53^{\prime} \mathrm{E}\right)$ using a bottom 
trawl. Animals were immediately transported to the laboratory of the Marine Biological Station Helgoland (Biologische Anstalt Helgoland (BAH)) where they were maintained individually in flow-through seawater aquaria $(15-201)$ at sea-surface temperature $\left(15.2-17.2^{\circ} \mathrm{C}\right)$ and salinity $(\sim 32 \mathrm{psu})$ in a 12:12-hour light/dark cycle. Adults were fed twice a week either with isopods (Idotea sp.) or pieces of mussel (Mytilus edulis) meat. One day after feeding, remains were removed from the aquaria to maintain good water quality.

Freshly hatched larvae were collected in filters receiving water from the overflow of the aquaria. Since most larvae hatched at night, samples were taken every morning. Filters were cleaned every evening to ensure daily larval age did not vary by more than 12 hours (Lovrich et al., 2003). Solely actively moving larvae were used for experiments.

\section{Influence of temperature on larval development}

Randomly selected larvae from one randomly selected female (A) were kept in $500 \mathrm{ml}$ glass bowls with a density of 20 to 30 individuals per bowl. In daily intervals, water was changed; larvae checked for moults or mortality and subsequently were fed with freshly hatched Artemia spp. nauplii. One hatch (female A; Table 1) was divided on the day of hatching and subsequently reared at five constant temperatures $(6,10$, 14,18 and $24^{\circ} \mathrm{C}$ ). Larvae reared at $15^{\circ} \mathrm{C}$ resulted from a female caught in 1985 and were maintained and reared under the same condition as outlined above.

Minimum time of development for each instar was recorded assuming optimal developmental conditions in larvae (see Figure 1). Samples for determinations of larval dry weight (W) and elemental composition were taken immediately after hatching and later in intervals of one to ten days (see Table 1). Five replicates were collected, or fewer, when too few larvae were available. Each replicate consisted of 20-25 individuals in the Zoea I (Z I), but fewer (see Table 1) in the following (larger) instars.

\section{Elemental analyses (CHN)}

Carbon $(\mathrm{C})$, hydrogen $(\mathrm{H})$ and nitrogen $(\mathrm{N})$ contents were determined following Anger \& Dawirs (1982); in brief: larvae were gently rinsed in distilled water, blotted on filter paper, placed into tin cartridges, vacuum-dried for 48 hours at $<0.01$ mbar in a Lyovac GT $2 \mathrm{E}$ (Leybold-Heraeus) apparatus, weighed to the nearest $0.1 \mu \mathrm{g}$ on a Mettler $\mathrm{UM}_{3}$ microbalance, and stored frozen at $-20^{\circ} \mathrm{C}$. $\mathrm{CHN}$ content was measured with a Fisons (Carlo Erba Science) Model 1108 Elemental Analyzer.

In order to study intraspecific variability in the maternal energy provisioning of offspring, we sampled freshly hatched larvae from eight ovigerous females (always after the first night of the hatching period; female CW $=13$ $17 \mathrm{~cm}$; Table 2) and compared their initial body mass (measured as dry weight, W) and elemental composition (carbon, hydrogen and nitrogen; collectively $\mathrm{CHN}$ ).

\section{Enzyme assay}

Citrate synthase (CS) (E.C. 4.1.3.7) is a key regulatory enzyme in the tricarbonic acid (TCA) cycle and was chosen as an indicator of aerobic capacity. Investigations on metabolic enzymes in larval stages are scarce and studies on shrimp larvae show that CS activity is dependent on growth during ontogeny (Lemos et al., 2003). Samples for determinations of enzyme activity of CS were taken in the premoult period of the Zoea I instar of larvae reared at three temperatures (10, 14 and $18^{\circ} \mathrm{C}$ ) and analysed following a modified method of Sidell et al. (1987). Three replicates were collected, each consisting of 10 larvae. No samples were taken for $6^{\circ}$ and $24^{\circ} \mathrm{C}$ as an insufficient amount of material was available.

Frozen samples were homogenized in $\sim 0.3 \mu \mathrm{l}$ extraction buffer (75 mM Tris-HCl, $1 \mathrm{mM}$ EDTA; $\mathrm{pH}$ 7.6) per $1 \mu \mathrm{g}$ larval W (dry weight) to get a $1: 10(\mathrm{w} / \mathrm{v})$ ratio with a Branson Sonifier $450\left(\mathrm{o}^{\circ} \mathrm{C}\right.$, output control 8 , duty cycle $50 \%$, 15 minutes). Homogenates were centrifuged for 5 minutes at $7400 \mathrm{~g}$ and $0^{\circ} \mathrm{C}$ with an Eppendorf Centrifuge $5810 \mathrm{R}$. The concentration of soluble protein in the extracts was measured after Bradford (1976). The samples were first diluted 1:5 with 0.9\% $\mathrm{NaCl}$ and were then applied in duplicate $(5 \mu \mathrm{l})$ on microplates. Subsequently $250 \mu \mathrm{l}$ dye reagent (Biorad protein assay 500 ooo6, diluted 1:5 with aqua dest) were added and the optical density was measured at $620 \mathrm{~nm}$ in a microplate reader (FLUOstar Galaxy). Bovine serum albumin (BSA, $0-3.5 \mu \mathrm{g}$ per well) was run parallel as standard.

For enzyme assays the absorption of the supernatant was measured at four temperatures $\left(10,14,18\right.$ and $24^{\circ} \mathrm{C}$ ) in three aliquots with a microplate reader at $405 \mathrm{~nm}$. Homogenates $(2 \mu \mathrm{l} /$ well $)$ were assayed in $150 \mu \mathrm{l}$ of $100 \mathrm{mM}$ Tris-HCl buffer (pH 8.0), $10 \mu \mathrm{l} \quad 5 \mathrm{mM} \quad$ DTNB (5.5'-Dithio-bis-(2-nitrobenzoic acid)) and $4 \mu$ l Acetyl-CoA $(20 \mathrm{mM}) .4 \mu$ l Oxalacetat $(20 \mathrm{mM})$ was added to start the reaction (omitted for the blanks). Standards of $0.5 \mathrm{mM}$ Dithiothreitol DTT $(5-40 \mu \mathrm{l}$ per well) were run in parallel. The activity was expressed as the change of absorption per time and protein weight units $\left(\Delta \mathrm{A} \min _{\mathrm{gprt}^{-1}}{ }^{-1}\right)$.

\section{Statistical analyses}

All data were tested with the Nalimov test to exclude outliers from analysis (Kaiser \& Gottschalk, 1972). A general additive model (Hastie \& Tibshirani, 1990) was used to describe larval mass ( $\mu \mathrm{g} \mathrm{C})$ as a function of time (t, days) and temperature (T, Kelvin):

$$
C_{B C}=a+b_{1} \times t+b_{2} \times f(T)+b_{3} \times t \times f(T) \quad[\mu g, d, K]
$$

where $\mathrm{C}_{\mathrm{BC}}$ is the Box-Cox transformed larval mass (Sokal \& Rholf, 1981) and $f(\mathrm{~T})$ a function that models the temperature effect according to a normal distribution with mean $\mathrm{M}_{\mathrm{T}}$, standard deviation $\mathrm{SD}_{\mathrm{T}}$ and skewing factor $\mathrm{SK}_{\mathrm{T}}$. The latter was introduced to allow for asymmetric effects of temperatures above and below the optimum, as observed in many temperature tolerance studies (see e.g. Pörtner et al., 2001, 2005) and implied by the original data:

$$
\begin{array}{cc}
f(t)=\left(1 /\left(S D_{T} \times \sqrt{2 \pi}\right)\right) \times e^{-0.5 \times\left(\left(\left(T-M_{T}\right)+S K_{T} \times\left(T-M_{T}\right)\right) / S D_{T}\right)^{2}} & \text { for } \mathrm{T}>=\mathrm{M}_{\mathrm{T}} \\
f(t)=\left(1 /\left(S D_{T} \times \sqrt{2 \pi}\right)\right) \times e^{-0.5 \times\left(\left(\left(T-M_{T}\right)-S K_{T} \times\left(T-M_{T}\right)\right) / S D_{T}\right)^{2}} & \text { for } \mathrm{T}<\mathrm{M}_{\mathrm{T}}
\end{array}
$$

For the comparison of elemental composition of larvae of different females and temperature dependence of CS activity a one-way ANOVA was used. Post-hoc tests were conducted 
Table 1. Cancer pagurus. Changes in dry weight $(W)$, carbon $(C)$, nitrogen $(N)$ and C:N ratio during time days after hatch ( \pm SD) at five temperatures. Larvae reared at $15^{\circ} \mathrm{C}$ are from different female.

\begin{tabular}{|c|c|c|c|c|c|c|c|c|c|c|c|}
\hline \multirow[t]{2}{*}{ Temp $\left({ }^{\circ} \mathrm{C}\right)$} & \multirow[t]{2}{*}{ Instar } & \multicolumn{2}{|c|}{ Individual/sample } & \multicolumn{2}{|c|}{ Time/days } & \multicolumn{2}{|c|}{$\mathrm{DM}(\boldsymbol{\mu g}) \mathrm{C}(\boldsymbol{\mu g})$} & \multicolumn{2}{|l|}{$\mathrm{N}(\mu \mathrm{g})$} & \multicolumn{2}{|l|}{$\mathrm{C} / \mathrm{N}$} \\
\hline & & & & Mean & $\pm \mathrm{SD}$ & Mean & $\pm \mathrm{SD}$ & Mean & $\pm \mathrm{SD}$ & Mean & $\pm \mathrm{SD}$ \\
\hline \multirow[t]{12}{*}{6} & $\mathrm{ZI}$ & 25 & o & 15.6 & 0.5 & 5.00 & 0.09 & 1.19 & 0.02 & 4.22 & 0.01 \\
\hline & $\mathrm{ZI}$ & 24 & 2 & 16.0 & 0.8 & 5.27 & 0.21 & 1.21 & 0.05 & 4.35 & 0.02 \\
\hline & $\mathrm{ZI}$ & 22 & 4 & 18.0 & 0.6 & $5 \cdot 51$ & 0.11 & 1.28 & 0.02 & 4.31 & 0.03 \\
\hline & $\mathrm{ZI}$ & 21 & 6 & 17.7 & 0.5 & 5.60 & 0.18 & 1.30 & 0.04 & 4.30 & 0.02 \\
\hline & $\mathrm{ZI}$ & 21 & 8 & 19.2 & 0.3 & 5.56 & 0.16 & 1.31 & 0.04 & 4.26 & 0.02 \\
\hline & $\mathrm{ZI}$ & 21 & 10 & 19.0 & 0.5 & 5.68 & 0.21 & 1.35 & 0.05 & 4.22 & 0.02 \\
\hline & $\mathrm{ZI}$ & 21 & 12 & 19.0 & 1.0 & 5.36 & 0.20 & 1.28 & 0.05 & 4.19 & 0.02 \\
\hline & ZI & 21 & 15 & 18.3 & 0.5 & 5.45 & 0.04 & 1.33 & 0.04 & 4.15 & 0.02 \\
\hline & $\mathrm{ZI}$ & 21 & 17 & 19.4 & 0.3 & 6.29 & 0.07 & 1.48 & 0.01 & 4.26 & 0.03 \\
\hline & ZI & 21 & 19 & 19.8 & 0.8 & 5.97 & 0.15 & 1.40 & 0.04 & 4.27 & 0.03 \\
\hline & ZI & 21 & 21 & 22.9 & 0.5 & 7.34 & 0.03 & 1.74 & 0.01 & 4.22 & 0.01 \\
\hline & $\mathrm{ZI}$ & 21 & 25 & 20.8 & 0.1 & 6.97 & 0.14 & 1.69 & 0.04 & 4.12 & 0.01 \\
\hline \multirow[t]{8}{*}{10} & ZI & 25 & o & 15.6 & 0.5 & 5.00 & 0.09 & 1.19 & 0.02 & 4.22 & 0.01 \\
\hline & ZI & 24 & 2 & 18.4 & 0.5 & 5.93 & 0.19 & 1.32 & 0.04 & 4.47 & 0.01 \\
\hline & ZI & 22 & 4 & 20.3 & 0.2 & 6.34 & 0.15 & 1.43 & 0.03 & 4.44 & 0.03 \\
\hline & ZI & 21 & 6 & 20.2 & 0.2 & 6.49 & 0.16 & 1.48 & 0.03 & 4.38 & 0.04 \\
\hline & ZI & 21 & 8 & 21.3 & 0.3 & 6.26 & 0.12 & 1.47 & 0.04 & $4 \cdot 32$ & 0.01 \\
\hline & $\mathrm{ZI}$ & 21 & 10 & 20.6 & 0.6 & 5.97 & 0.25 & 1.41 & 0.07 & 4.23 & 0.02 \\
\hline & ZI & 21 & 12 & 20.7 & 0.7 & 5.94 & 0.26 & 1.42 & 0.06 & 4.19 & 0.01 \\
\hline & ZII & 20 & 15 & 26.1 & 0.8 & 9.36 & 0.30 & 2.26 & 0.03 & 4.21 & 0.01 \\
\hline \multirow[t]{8}{*}{14} & $\mathrm{ZI}$ & 25 & 0 & 15.6 & 0.5 & 5.00 & 0.09 & 1.19 & 0.02 & 4.22 & 0.01 \\
\hline & ZI & 24 & 2 & 18.3 & 0.7 & 5.69 & 0.17 & 1.28 & 0.04 & 4.45 & 0.02 \\
\hline & ZI & 22 & 4 & 18.5 & 1.4 & 5.98 & 0.43 & 1.35 & 0.10 & 4.45 & 0.01 \\
\hline & ZI & 21 & 6 & 21.5 & 0.3 & 6.95 & 0.33 & 1.58 & 0.08 & 4.39 & 0.03 \\
\hline & ZII & 20 & 7 & 21.6 & 0.2 & 6.80 & 0.21 & 1.55 & 0.04 & 4.39 & 0.02 \\
\hline & ZIII & 7 & 16 & 41.0 & 1.3 & 14.21 & 0.43 & 3.36 & 0.10 & 4.22 & 0.03 \\
\hline & ZIV & 5 & 23 & 63.4 & 4.7 & 23.32 & 1.96 & 5.42 & 0.45 & 4.30 & 0.05 \\
\hline & $\mathrm{ZV}$ & 2 & 33 & 105.6 & 3.9 & 40.86 & 0.99 & 9.23 & 0.30 & 4.43 & 0.05 \\
\hline \multirow[t]{21}{*}{15} & ZI & 20 & o & 14.7 & 0.8 & 5.0 & 0.2 & 1.2 & 0.1 & 4.15 & 0.18 \\
\hline & ZI & 15 & 1 & 19.1 & 0.5 & 6.2 & 0.1 & 1.5 & 0.0 & 4.1 & 0.08 \\
\hline & ZI & 15 & 2 & 21.0 & 0.9 & 7.2 & 0.4 & 1.7 & 0.1 & 4.29 & 0.1 \\
\hline & $\mathrm{ZI}$ & 15 & 3 & 21.8 & 0.9 & 7.6 & 0.4 & 1.7 & 0.1 & 4.54 & 0.12 \\
\hline & ZI & 15 & 4 & 22.2 & 1.4 & 8.4 & 0.5 & 1.9 & 0.1 & 4.52 & 0.09 \\
\hline & ZI & 15 & 5 & 23.9 & 1.5 & 8.8 & 0.6 & 2.0 & 0.1 & 4.4 & 0.11 \\
\hline & ZI & 15 & 6 & 23.9 & 1.4 & 8.7 & 0.6 & 2.0 & 0.2 & 4.28 & 0.1 \\
\hline & $\mathrm{ZI}$ & 15 & 7 & 22.4 & 0.6 & 8.6 & 0.2 & 2.1 & 0.1 & 4.09 & 0.11 \\
\hline & ZII & 15 & 8 & 25.3 & 1.1 & 8.8 & 0.3 & 2.1 & 0.1 & 4.15 & 0.08 \\
\hline & ZII & 10 & 10 & 34.8 & 1.9 & 12.6 & 0.6 & 2.8 & 0.1 & 4.54 & 0.09 \\
\hline & ZII & 10 & 12 & 39.9 & 1.6 & 14.7 & 0.6 & 3.4 & 0.2 & 4.37 & 0.09 \\
\hline & ZII & 10 & 14 & 37.4 & 3.5 & 14.0 & 1.4 & 3.4 & 0.4 & 4.17 & 0.06 \\
\hline & ZIII & 7 & 15 & 43.7 & 3.0 & 14.2 & 0.7 & 3.4 & 0.2 & 4.17 & 0.17 \\
\hline & ZIII & 7 & 17 & 52.1 & 6.5 & 17.0 & 2.4 & 3.7 & 0.5 & 4.57 & 0.23 \\
\hline & ZIII & 7 & 19 & 63.9 & 1.9 & 22.3 & 0.7 & 5.0 & 0.3 & 4.5 & 0.15 \\
\hline & ZIII & 7 & 21 & 62.2 & 7.5 & 23.9 & 3.4 & 5.5 & 0.8 & 4.35 & 0.16 \\
\hline & ZIV & 7 & 22 & 63.0 & & 19.9 & & 4.8 & & 4.12 & \\
\hline & ZIV & 5 & 23 & 83.9 & $4 \cdot 3$ & 27.5 & 2.1 & 6.0 & 0.5 & 4.6 & 0.1 \\
\hline & ZIV & 5 & 24 & 93.9 & 18.0 & 32.2 & 6.9 & 7.0 & 1.4 & 4.57 & 0.11 \\
\hline & ZIV & 4 & 26 & 120.4 & & 43.0 & & 9.6 & & 4.49 & \\
\hline & ZV & 3 & 38 & 129.0 & 8.5 & 45.7 & 3.7 & 11.0 & 0.6 & 4.15 & 0.23 \\
\hline \multirow[t]{5}{*}{18} & $\mathrm{ZI}$ & 25 & 0 & 15.6 & 0.5 & 5.00 & 0.09 & 1.19 & 0.02 & 4.22 & 0.01 \\
\hline & ZI & 24 & 2 & 18.8 & 0.7 & 5.55 & 0.17 & 1.25 & 0.03 & 4.42 & 0.01 \\
\hline & ZI & 20 & 3 & 19.3 & 0.8 & 6.03 & 0.25 & 1.36 & 0.05 & 4.41 & 0.02 \\
\hline & $\mathrm{ZI}$ & 22 & 4 & 20.8 & 0.3 & 6.46 & 0.26 & 1.51 & 0.06 & 4.28 & 0.01 \\
\hline & ZII & 20 & 6 & 24.3 & 1.9 & 8.23 & 0.38 & 1.87 & 0.16 & 4.41 & 0.18 \\
\hline \multirow[t]{4}{*}{24} & $\mathrm{ZI}$ & 25 & 0 & 15.6 & 0.5 & 5.00 & 0.09 & 1.19 & 0.02 & 4.22 & 0.01 \\
\hline & $\mathrm{ZI}$ & 24 & 2 & 19.6 & 2.9 & 5.86 & 0.83 & 1.31 & 0.22 & 4.50 & 0.11 \\
\hline & ZII & 22 & 4 & 22.8 & 0.3 & 8.15 & 0.05 & 1.90 & 0.01 & $4 \cdot 30$ & 0.03 \\
\hline & ZIII & 17 & 10 & 33.9 & 3.8 & 11.55 & 1.52 & 2.73 & 0.38 & 4.24 & 0.03 \\
\hline
\end{tabular}




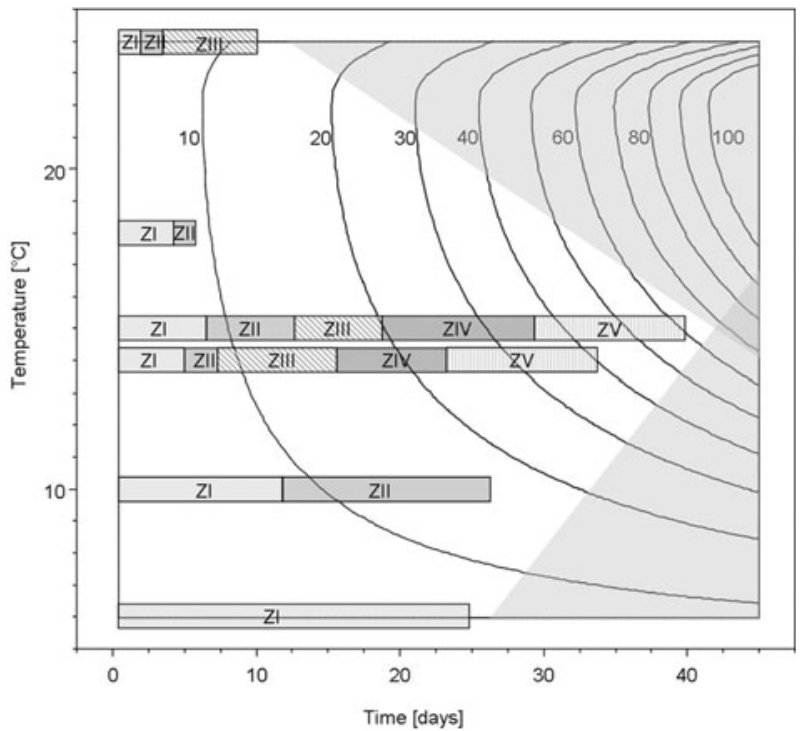

Fig. 1. Model of body mass increase (C) throughout the larvae development of the edible crab Cancer pagurus. Equation for the model is: $C_{B C}=-7.97-10.755 \times t+919.52 \times f(T)+476.634 \times t \times f(T) ; \mathrm{N}=463$ $\mathrm{F}=1599.51, \mathrm{R}^{2}=0.954 ; \mathrm{T}$ represents the temperature in Kelvin and the time in days. Isolines represent carbon content in $\mu \mathrm{g}$. ZI-ZV are the larval instars. White areas show the realistic range of the model.

with the Student-Newman-Keuls method. C/N ratio data were transformed logarithmically prior to analysis in order to achieve a normally distributed data set.

\section{RESULTS}

\section{Influence of temperature on larval development}

Complete zoeal development occurred only at 14 and $15^{\circ} \mathrm{C}$ (Table 1; Figure 1). At $6^{\circ} \mathrm{C}$, the Zoea I survived for up to 25 days without moulting to the Zoea II stage. At $10^{\circ} \mathrm{C}$, first larvae moulted after 12 days to the Zoea II and survived only for another three days. Larvae reared at $14^{\circ} \mathrm{C}$ reached the Zoea V 33 days after hatching. At $18^{\circ} \mathrm{C}$, larvae died already after 6 days in the Zoea II stage, and at $24^{\circ} \mathrm{C}$ they reached the Zoea III, dying ten days later.

The minimum duration of development through the ZI stage decreased with increasing temperature. This pattern can be described as a linear relationship between ln temperature and $\ln$ instar duration with the equation:

$$
\ln \mathrm{D}=\ln 6.5482-1.8096 \times \ln T ; \mathrm{R}^{2}=0.991, P<0.001
$$

where $\mathrm{D}=$ time of development (days) and $\mathrm{T}=$ temperature $\left({ }^{\circ} \mathrm{C}\right)$. Changes in $\mathrm{W}$ and $\mathrm{CHN}$ during the course of larval development are shown in Table 1.

Larval body mass $(\mathrm{C}$ in $\mu \mathrm{g} /$ ind) is predicted from day $(\mathrm{t})$ and temperature ( $\mathrm{T}$ in $\mathrm{K}$ ) by the model

$$
\begin{gathered}
C_{B C}=-7.97-10.755 \times t+919.52 \times f(T)+476.634 \times t \times f(T) \\
\mathrm{N}=463, \quad \mathrm{~F}=1599.51, \quad \mathrm{R}^{2}=0.954, \quad P<0.001 \text { for the }
\end{gathered}
$$
whole model and each term with

$f(T)=0.02452 \times e^{-0.5 \times\left((((T-295.243)+(T-295.243)+0.620 \times(T-295.243)) \div 16.273)^{2}\right)}$ for $\mathrm{T}>=295.243$

$f(T)=0.02452 \times e^{-0.5 \times\left((((T-295.243)+(T-295.243)-0.620 \times(T-295.243)) \div 16.273)^{2}\right)}$ for $T<295.243$

using

$$
C_{B C}=\left(C^{0.2}-1\right) / 0.0283318325559
$$

this solves to

$$
C=(0.779-0.305 \times t+26.0517 \times f(T)+13.504 \times t \times f(T))^{5}
$$

Note that this model predicts a larval mass for just any combination of time and temperature whereas our experiments indicate that the time $\times$ temperature space where larvae do exist is limited (see discussion). Figure 1 provides a plot of larval mass in the time $\times$ temperature space, where the 'unrealistic' range has been shadowed. The residual plot (Figure 2) indicates that the model fit the data quite well up to about $40 \mu \mathrm{g} \mathrm{C}$, but severely underestimates larval mass $>50 \mu \mathrm{g}$ C. At the upper threshold temperatures in higher instars, changes in carbon values were generally lower than predicted by the model (see Figure 2). Further increase or decrease in temperature cause death of the larvae. To give an example: at $6^{\circ} \mathrm{C}$ larvae did not moult and die after 25 days; at $24^{\circ} \mathrm{C}$, carbon values in the Zoea III are much lower than they were predicted by the model (also compare Table 1 ), e.g. $20^{\circ} \mathrm{C}$, and the larvae died before reaching the Zoea IV. According to the model, the

\begin{tabular}{|c|c|c|c|c|c|c|c|c|c|c|c|}
\hline \multirow[t]{2}{*}{ Female } & \multirow[t]{2}{*}{$\mathrm{CW}(\mathrm{cm})$} & \multicolumn{2}{|c|}{$\mathrm{W}(\boldsymbol{\mu} \mathbf{g})$} & \multicolumn{2}{|l|}{$\mathrm{C}(\boldsymbol{\mu} \mathrm{g})$} & \multicolumn{2}{|c|}{$\mathbf{N}(\boldsymbol{\mu g})$} & \multicolumn{2}{|c|}{$\mathbf{H}(\boldsymbol{\mu} \mathbf{g})$} & \multicolumn{2}{|c|}{$\mathrm{C} / \mathrm{N}(\boldsymbol{\mu} \mathrm{g})$} \\
\hline & & Mean & $\pm S D$ & Mean & $\pm S D$ & Mean & $\pm \mathrm{SD}$ & Mean & $\pm \mathrm{SD}$ & Mean & $\pm \mathrm{SD}$ \\
\hline A & 16.8 & 15.6 & 0.5 & 5.00 & 0.09 & 1.19 & 0.02 & 0.71 & 0.01 & 4.22 & 0.01 \\
\hline B & 14.2 & 18.0 & 0.4 & 5.83 & 0.01 & 1.33 & 0.00 & 0.84 & 0.01 & 4.40 & 0.02 \\
\hline $\mathrm{C}$ & 14.3 & 17.1 & 0.1 & 5.54 & 0.07 & 1.29 & 0.01 & 0.78 & 0.00 & 4.28 & 0.01 \\
\hline $\mathrm{D}$ & 14.2 & 16.1 & 0.2 & 5.01 & 0.05 & 1.14 & 0.01 & 0.69 & 0.02 & 4.38 & 0.01 \\
\hline $\mathrm{E}$ & 12.5 & 14.4 & 0.3 & 4.79 & 0.06 & 1.13 & 0.01 & 0.66 & 0.02 & 4.22 & 0.01 \\
\hline $\mathrm{F}$ & 13.2 & 12.5 & 0.3 & 4.87 & 0.08 & 1.16 & 0.01 & 0.68 & 0.01 & 4.17 & 0.01 \\
\hline G & 17.1 & 15.7 & 0.2 & 5.56 & 0.08 & 1.28 & 0.01 & 0.79 & 0.01 & $4 \cdot 34$ & 0.02 \\
\hline $\mathrm{H}$ & 13.6 & 12.1 & 0.3 & 4.65 & 0.15 & 1.13 & 0.04 & 0.67 & 0.03 & 4.13 & 0.01 \\
\hline
\end{tabular}
final Zoea $\mathrm{V}$ body mass of $60 \mu \mathrm{g} \mathrm{C}$ observed at $16^{\circ} \mathrm{C}$ would be obtained after 36 days at $18^{\circ} \mathrm{C}$, which already lies outside

Table 2. Cancer pagurus. Size of eight different females and elemental composition (dry weight (W), carbon (C), nitrogen (N), hydrogen (H), C:N and $\mathrm{C}: \mathrm{H}$ ratio of freshly hatched larvae (hatch 1 )). 


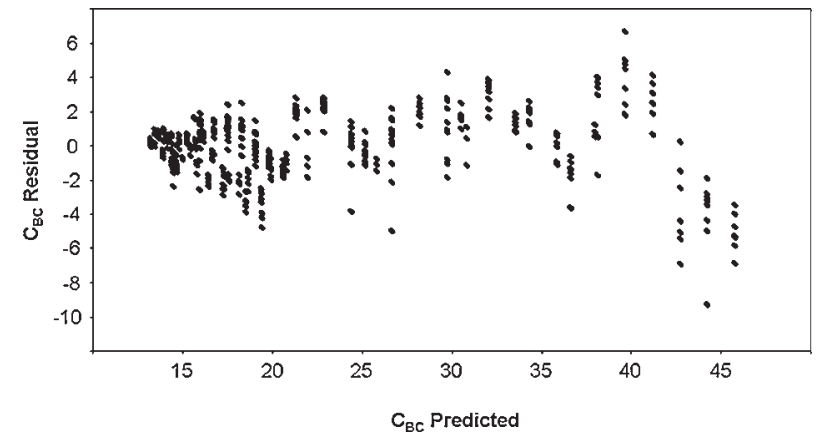

Fig. 2. Residual by predicted plot from the model predicting larval growth: plot of regression residuals versus predicted values. The plot does not indicate a problem with the model.

the realistic assumption, and would be unattainable at temperatures $<=10^{\circ} \mathrm{C}$.

\section{Citrate synthase activity (CSA)}

Activities of citrate synthase (CS) in C. pagurus larvae measured at four different temperatures are shown in Figure 3. Larvae of all acclimation temperatures show lowest activity levels at $10^{\circ} \mathrm{C}$ assay temperature. $14^{\circ} \mathrm{C}$ acclimated larvae show the highest activity at all assay temperatures. $18^{\circ} \mathrm{C}$ acclimated larvae show no significant differences over the whole measured temperature range. Significantly higher CSA rates compared to larvae at hatching are only observed at $14^{\circ} \mathrm{C}$ assay temperature.

\section{Variability in initial larval body mass among broods}

Female carapace width (CW), larval body weight (W) and elemental composition $(\mathrm{CHN})$ are compared in Table 2. Initial body mass and elemental composition of freshly hatched Zoea I larvae varied significantly among the eight females (Table 3) without showing a clear pattern between

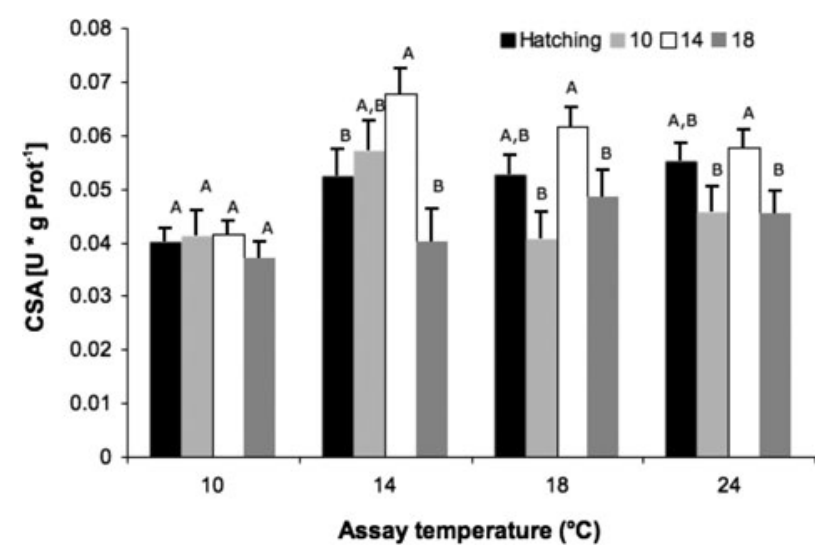

Fig. 3. Citrate synthase activity $\left(\mathrm{U}^{*} \mathrm{~g} \operatorname{Prot}^{-1}\right)$ of Cancer pagurus larvae acclimated to three different temperatures (light grey bars $-10^{\circ} \mathrm{C}$ acclimated white bars $-14^{\circ} \mathrm{C}$ acclimated; dark grey bars $-18^{\circ} \mathrm{C}$ acclimated) compared with larvae immediately after hatching (black bars). Bars within an assay temperature not connected with the same letter are significantly different $(P>0.05)$.
Table 3. Cancer pagurus. One-way ANOVA to evaluate the maternal influence on body mass (as dry weight (W), carbon (C), and nitrogen $(\mathrm{N})$ ]) and C:N ratio of freshly hatched larvae (first day of the hatching period 1). ${ }^{*}$, ANOVA on ranks because equal variance test failed.

\begin{tabular}{llrrl}
\hline & df & MS & F & \multicolumn{1}{l}{} \\
\hline $\mathrm{W}$ & 7 & 16.873 & 177.957 & $<0.001$ \\
$\mathrm{C}$ & 7 & 0.765 & 99.901 & $<0.001$ \\
$\mathrm{~N}^{*}$ & 7 & & & $<0.001$ \\
$\mathrm{C} / \mathrm{N}$ & 7 & 0.0023 & 244.893 & $<0.001$ \\
\hline
\end{tabular}

larval energy provisioning and female size. For example, females $\mathrm{B}$ and $\mathrm{D}$ had the same $\mathrm{CW}$, but larval $\mathrm{W}$ and $\mathrm{C}, \mathrm{H}$, and $\mathrm{N}$ contents differed significantly.

\section{DISCUSSION}

Larval development of C. pagurus of the Helgoland population up to Zoea $\mathrm{V}$ is achieved within a narrow temperature window $\left(15-16^{\circ} \mathrm{C}\right)$ only. Below and above this window we see initial development that completes stages Zoea I to Zoea III, depending on temperature. Zoea I development times indicate a positive temperature effect on larval growth up to $24^{\circ} \mathrm{C}$, too. Our predictive model captures this feature quite well, indicating that optimum temperature should be around $22^{\circ} \mathrm{C}$. Hence, what causes the failure of larval development outside the $15-16^{\circ} \mathrm{C}$ window? Obviously, this is not a straightforward temperature effect on metabolism, e.g. through cellular oxygen deficiency beyond Pejus temperatures as postulated by Pörtner (2001). Additionally, reduced feeding activity at cold temperatures can result in insufficient ingestion rates, while at high temperatures higher maintenance costs cannot be compensated (Dawirs \& Dietrich, 1986; Anger et al., 2004; Heilmayer et al., 2008). We hypothesize that the transition from one stage to the next is the phase of failure. Either, energy investment and thus oxygen demand is distinctly enhanced during transition from one stage to the next, and/or the complex metamorphotic process by itself is more temperature sensitive, as it has long been known that ecdysis is the critical point in the development of decapod larvae (Anger, 2001).

The residual plot (Figure 2) shows a general good fit of the model (i.e. random distribution of residuals) and slightly lower carbon values in higher instars $(\mathrm{Z} \mathrm{V})$ than predicted by the model (Figure 2), which might be due to problems during metamorphosis to the megalopa stage. It is known that larvae are able to postpone their metamorphosis to the megalopa stage if the cue for the suitable habitat cannot be detected (Krimsky \& Epifanio, 2008), but the enduring lack of those cues cause stress and the depletion of resources.

Changes in the kinetic characteristics of enzymes reflect differences in metabolic regulation and are inevitably involved in adaptation and acclimation to ambient temperature (Wells et al., 2001; Somero, 2005). A decrease in CS activity is a strong indication for metabolic reduction. In C. pagurus CSA decreases with increasing enzyme assay temperature, indicating an optimum temperature at $14^{\circ} \mathrm{C}$. The generally lower citrate synthase activity, i.e. lower aerobic capacity, of $18^{\circ} \mathrm{C}$ larvae over the whole measured temperature range indicate that acclimation to above-optimum temperatures cannot 
be compensated. The compensation over certain temperature ranges has been reported for several fish and crustaceans (e.g. Salomon \& Buchholz, 2000; Lannig et al., 2003; Lemos et al., 2003).

No complete larval development was observed in our laboratory experiments at $18^{\circ} \mathrm{C}$, although this is a temperature which larvae may encounter in Helgoland waters during summer. Only little information is available about the southern distribution boundaries, where larvae should encounter much warmer water temperatures. There is evidence for a northern expansion of this species in Norway (Woll et al., 2006), probably indicating that warming of the ocean drives an expansion if not shift of the geographical range of C. pagurus towards the northern North Sea (see also Wiltshire \& Manly, 2004). It is thus necessary to determine the significance of the temperature tolerance window of this species for its distribution boundaries more accurately.

In this context it might be important to recognize that initial larval biomass at hatching varied significantly within our small sample size $(\mathrm{N}=8)$ but without statistically significant correlation between female size and the body mass of freshly hatched Zoea I. However, it must be taken into consideration that our data $(12.5-17.1 \mathrm{~cm} \mathrm{CW})$ do not cover the whole size-range of mature females and thus future study investigating the full range of female maturity (11.5 to $19 \mathrm{~cm}$; Neal \& Wilson, 2004) may come to a different conclusion. Energy allocation of females into offspring may be controlled by genetic disposition (Reznick, 1981), size (DeMartini et al., 2003), temperature (Fischer \& Thatje, 2008), or the nutritional status of the female (Bernardo, 1996). A positive relationship between maternal size and offspring size has been observed in both invertebrates (Marshall \& Keough, 2004) and vertebrates (Birkeland \& Dayton, 2005), but not universally. Among crustaceans, there are species that show such a relationship, e.g. the xanthoid crab Pseudocarcinus gigas (Gardner, 1997), but also other species not following this pattern, e.g. the American lobster (Homarus americanus) (Ouellet \& Plante, 2004).

Future studies covering the full size-range of mature $C$. pagurus need to reveal whether intraspecific variability in energy offspring is a matter of individual variability in female fitness and/or a female size related trade off. Intraspecific variability may also affect larval fitness and survival and thus a future large-scale study is needed to reveal whether the herein reported temperature tolerance pattern for larvae from a single female can be easily translated into populations and consequently management approaches of this species.

\section{ACKNOWLEDGEMENTS}

We would like to thank U. Nettelmann for help with the larval culture maintenance and $\mathrm{K}$. Bickmeyer for $\mathrm{CHN}$-analyses. This study was partially conducted in the frame of the EU-project CENSOR (Climate variability and El Niño Southern Oscillation: Impacts for natural coastal resources and management) (Contract No. 511071) and is CENSOR publication No. 0309 with additional support by the Marine Biodiversity and Ecosystem Functioning Network of Excellence MarBEF (Contract No. GOCE-CT-2003-505446) of the FP6.

\section{REFERENCES}

Anger K. (2001) The biology of decapod crustacean larvae. Lisse: A.A. Balkema Publishers, Crustacean Issues 14, 420 pp.

Anger K. and Dawirs R.R. (1982) Elemental composition (C, N, H) and energy in growing and starving larvae of Hyas araneus (Decapoda, Majidae). Fisheries Bulletin 80, 419-433.

Anger K., Lovrich G.A., Thatje S. and Calcagno J.A. (2004) Larval and early juvenile development of Lithodes santolla (Molina, 1782) (Decapoda: Anomura: Lithodidae) reared at different temperatures in the laboratory. Journal of Experimental Marine Biology and Ecology 306, 217-230.

Bernardo J. (1996) The particular maternal effect of propagule size, especially egg size: patterns, models, quality of evidence and interpretations. American Zoologist 36, 216-236.

Birkeland C. and Dayton P.K. (2005) The importance in fishery management of leaving the big ones. Trends in Ecology and Evolution 20, $356-358$.

Bradford M.M. (1976) A rapid and sensitive method for the quantitation of microgram quantities of protein utilizing the principle of proteindye binding. Analytical Biochemistry 72, 248-254.

Dahlhoff E.P. (2004) Biochemical indicators of stress and metabolism: applications for marine ecological studies. Annual Review of Physiology 66, 183-207.

Dawirs R.R. (1979) Effects of temperature and salinity on larval development of Pagurus bernhardus (Decapoda, Paguridae). Marine Ecology Progress Series 1, 323-329.

Dawirs R.R. (1985) Temperature and larval development of Carcinus maenas (Decapoda) in the laboratory: prediction of larval dynamics in the sea. Marine Ecology Progress Series 24, 297-302.

Dawirs R.R. and Dietrich A. (1986) Temperature and laboratory feeding rates in Carcinus maenas L. (Decapoda: Portunidae) larvae from hatching through metamorphosis. Journal of Experimental Marine Biology and Ecology 99, 133-147.

DeMartini E.E., DiNardo G.T. and Williams H.A. (2003) Temporal changes in population density, fecundity, and egg size of the Hawaiian spiny lobster (Panulirus marginatus) at Necker Bank, Northwestern Hawaiian Islands. Fisheries Bulletin 101, 22-31.

Fischer S. and Thatje S. (2008) Temperature-induced oviposition in the brachyuran crab Cancer setosus along a latitudinal cline: aquaria experiments and analysis of field data. Journal of Experimental Marine Biology and Ecology 357, 157-164.

Gardner C. (1997) Effect of size on reproductive output of giant crabs Pseudocarcinus gigas (Lamarck): Oziidae. Marine and Freshwater Research 48, 581-587.

Giménez L. and Anger K. (2003) Larval performance in an estuarine crab, Chasmagnathus granulata, is a consequence of both larval and embryonic experience. Marine Ecology Progress Series 249, 251-264.

Giménez L. and Torres G. (2002) Larval growth in the estuarine crab Chasmagnathus granulata: the importance of salinity experienced during embryonic development, and the initial larval biomass. Marine Biology 141, 877-885.

Giménez L., Anger K. and Torres G. (2004) Linking life history traits in successive phases of a complex life cycle: effects of larval biomass on early juvenile development in an estuarine crab, Chasmagnathus granulata. Oikos 104, 570-580.

Harms J., Anger K., Klaus S. and Seeger B. (1991) Nutritional effects on ingestion rate, digestive enzyme activity, growth, and biochemical composition of Hyas araneus L. (Decapoda: Majidae) larvae. Journal of Experimental Marine Biology and Ecology 145, 233-265. 
Hastie T.J. and Tibshirani R.J. (1990) Generalized Additive Models. London: Chapman \& Hall/CRC Press, 335 pp.

Heilmayer O., Brey T. and Pörtner H.O. (2004) Growth efficiency and temperature in scallops: a comparative analysis of species adapted to different temperatures. Functional Ecology 18, 641-647.

Heilmayer O., Thatje S., McClelland C., Conlan K. and Brey T. (2008) Changes in biomass and elemental composition during early ontogeny of the Antarctic isopod crustacean Ceratoserolis trilobitoides. Polar Biology 31, 1325-1331.

Ingle R.W. (1981) The larval and post-larval development of the edible crab, Cancer pagurus Linnaeus (Decapoda: Brachyura). Bulletin of the British Musuem of Natural History (Zoology) 40, 211-236.

Kaiser R. and Gottschalk G. (1972) Ausreissertest nach Nalimov. Elementare Tests zur Beurteilung von Messadaten. Mannheim, Wien, Zürich: Bibliographisches Institut, pp. 18-21.

Krimsky L.S. and Epifanio C.E. (2008) Multiple cues from multiple habitats: effect on metamorphosis of the Florida stone crab, Menippe mercenaria. Journal of Experimental Marine Biology and Ecology 358, $178-184$.

Lannig G., Eckerle L.G., Serendero I., Sartoris F.J., Fischer T., Knust R., Johansen T. and Pörtner H.O. (2003) Temperature adaptation in eurythermal cod (Gadus morhua): a comparison of mitochondrial enzyme capacities in boreal and Arctic populations. Marine Biology $142,589-599$.

Lemos D., Salomon M., Gomes V., Phan V.N. and Buchholz F. (2003) Citrate synthase and pyruvate kinase activity during early life stages of the shrimp Farfantepenaeus paulensis (Crustacea, Decapoda, Penaeidae): effects of development and temperature. Comparative Biochemistry and Physiology B 135, 707-719.

Lovrich G.A., Thatje S., Calcagno J.A., Anger K. and Kaffenberger A. (2003) Changes in biomass and chemical composition during lecithotrophic larval development of the southern king crab, Lithodes santolla (Molina). Journal of Experimental Marine Biology and Ecology 288, $65-79$.

Marshall D.J. and Keough M.J. (2004) When the going gets rough: effect of maternal size manipulation on larval quality. Marine Ecology Progress Series 272, 301-305.

Neal K.J. and Wilson E. (2004) Cancer-pagurus. Edible crab. Marine Life Information. Network: Biology and Sensitivity Key Information Sub-programme (online). Plymouth: Marine Biological Association of the United Kingdom.

Pörtner H.O. (2001) Climate change and temperature-dependent biogeography: oxygen limitation of thermal tolerance in animals. Naturwissenschaften 88, 137-146.

Pörtner H.O., Berdal B., Blust R., Brix O., Colosimo A., Wachter B., Giuliani A., Johansen T., Fischer T., Knust R., Lannig G., Naevdal G., Nedenes A., Nyhammer G., Sartoris F.J., Serendero I., Sirabella P., Thorkildsen S. and Zakhartsev M. (2001) Climate induced temperature effects on growth performance, fecundity and recruitment in marine fish: developing a hypothesis for cause and effect relationships in Atlantic cod (Gadus morhua) and common eelpout (Zoarces viviparus). Continental Shelf Research 21, 1975-1997.
Pörtner H.O., Storch D. and Heilmayer O. (2005) Constraints and tradeoffs in climate dependent adaptation: energy budgets and growth in a latitudinal cline. Scientia Marina 69, 39-55.

Ouellet P. and Plante F. (2004) An investigation of the sources of variability in American lobster (Homarus americanus) eggs and larvae: female size and reproductive status, and interannual and interpopulation comparisons. Journal of Crustacean Biology 24, 481-495.

Reznick D. (1981) 'Grandfather effects': the genetics of interpopulation differences in offspring size in the Mosquito Fish. Evolution 35, 941-953.

Salomon M. and Buchholz F. (2000) Effects of temperature on the respiration rates and the kinetics of citrate synthase in two species of Idotea (Isopoda, Crustacea). Comparative Biochemistry and Physiology 125, $71-81$.

Sidell B.D., Driedzic W.R., Stowe D.B. and Johnston I.A. (1987) Biochemical correlations of power development and metabolic fuel preferenda in fish hearts. Physiological Zoology 60, 221-232.

Sokal R.R. and Rohlf F.J. (1981) Biometry - the principles and practice of statistics in biological research. San Francisco: W.H. Freeman, 859 pp.

Somero G.N. (2005) Linking biogeography to physiology: evolutionary and acclimatory adjustments of thermal limits. Frontiers in Zoology 2.

Thatje S., Anger K., Calcagno J.A., Lovrich G.A., Pörtner H.O. and Arntz W.E. (2005) Challenging the cold: crabs reconquer the Antarctic. Ecology 86, 619-625.

Torres C.G. and Escribano R. (2003) Growth and development of Calanus chilensis nauplii reared under laboratory conditions: testing the effects of temperature and food resources. Journal of Experimental Marine Biology and Ecology 294, 81-99.

Wells R.M.G., Lu J., Hickey A.J.R. and Jeffs A.G. (2001) Ontogenetic changes in enzyme activities associated with energy expenditure during development in the spiny lobster, Jasus edwardsii. Comparative Biochemistry and Physiology 130, 339-347.

Wiltshire K.H. and Manly B.F.J. (2004) The warming trend at Helgoland Roads, North Sea: phytoplankton response. Helgoland Marine Research 58, 269-273.

and

Woll A.K., van der Meeren G.I. and Fossen I. (2006) Spatial variation in abundance and catch composition of Cancer pagurus in Norwegian waters: biological reasoning and implications for assessment. ICES Journal of Marine Science 63, 421-433.

\section{Correspondence should be addressed to:} S. Thatje

National Oceanography Centre, Southampton

School of Ocean and Earth Science, University of Southampton

European Way, SO14 3ZH Southampton, United Kingdom email: svth@noc.soton.ac.uk 